\title{
Rasionalitas Beragama Pekerja Seks Komersial (PSK)
}

Indonesian Journal of Religion and Society, 2020, Vol. 02 (02), 129-137

(C) The Journal, 2020

DOI: $10.36256 /$ ijrs.v2i2.113

$\underline{\text { www.journal.lasigo.org/index.php/IJRS }}$

acher

Journal

Article History

Received: October $8^{\text {th }}, 2020$

Revised: December 28th 2020

Accepted: December 29th, 2020

\section{Rahmi Putri}

Universitas Islam Negeri (UIN) Imam Bonjol Padang, Indonesia

rahmiputri854@gmail.com

\section{Syafruddin}

Universitas Islam Negeri (UIN) Imam Bonjol Padang, Indonesia syafruddin@uinib.ac.id

\begin{abstract}
ABSTRAK
Artikel ini bertujuan untuk mengeksplorasi rasionalitas beragama di kalangan Pekerja Seks Komersial (PSK). Studi ini merupakan studi kasus dengan metode deskriptif kualitatif di Panti Sosial Karya Wanita Andam Dewi, Solok. Data dikumpulkan melalui wawancara mendalam. Menggunakan teori rasionalitas Max Weber sebagai alat analisis, studi ini menemukan beberapa temuan penting. Pertama, pilihan untuk terjun ke dunia prostitusi merupakan tindakan rasional yang dilakukan oleh perempuan pelacur. Tindakan melacur yang dilakukan adalah tindakan yang berorientasi tujuan (instrumentally rasional). Tindakan melacur, secara rasional bertujuan untuk mendapatkan utility, baik untuk menampakkan "dirinya" sebagai perempuan ataupun sebagai orang yang bertanggungjawab di dalam keluarga. Kedua, bagi perempuan pelacur, melacur dan beragama sama-sama menguntungkan. Melacur dapat memberdayakan keluarga dan meningkatkan perekonomian, beragama dapat mengurangi dan menghilangkan dosa melacur. Agama tidak saja dimaknai sebagai doktrin yang hanya mengatur pada aspek ritual saja seperti shalat, puasa dan segala macamnya, namun lebih dari itu agama dimaknai sebagai obat penawar untuk setiap tindakan seks yang dilakukan dalam melacur.
\end{abstract}

Kata Kunci: Pekerja Seks Komersial (PSK), Rasionalisasi, Agama, Seks.

\section{ABSTRACT}

This paper aims to explore religious rationality among prostitutes. This study is a case study with a qualitative descriptive method at the Panti Sosial Karya Wanita Andam Dewi Solok. Data was collected using in-depth interview techniques. Using Max Weber's rationality theory as an analytical tool, this study found several important findings. First, the choice to enter the world of prostitution is a rational action taken by prostitutes. The act of prostitution that is carried out is an action that is goal-oriented (instrumentally rational). Actions of prostitution are rationally strived to gain utility, either to show "himself" as a woman or as a person who is responsible in his family. Second, for prostitutes, between prostitution and religion, both are profitable. Prostitution can empower families and improve the economic sector, while religion can reduce and eliminate the sin of prostitution. Religion is not only interpreted as a doctrine that only regulates ritual aspects such as prayer, fasting and all kinds of things, but more than that religion is interpreted as an antidote for any sexual act committed in prostitution.

Kata Kunci: Prostitutes, Rationalization, Religion, Sex. 


\section{Pendahuluan}

Melacur didefinisikan oleh Perkins dan Bennet sebagai tindakan transaksi bisnis yang disepakati oleh pihak yang terlibat sebagai sesuatu yang bersifat kontrak jangka pendek yang memungkinkan satu orang atau lebih mendapatkan kepuasan seks dengan metode yang beraneka ragam. Selain itu, dengan perspektif ekonomi Soerjono Soekanto menjelaskan bahwa pelacuran dapat diartikan sebagai suatu pekerjaan yang bersifat menyerahkan diri kepada umum untuk melakukan perbuatan-perbuatan seksual dengan mendapatkan upah (Hidayah, 2016). Sedangkan PSK adalah perempuan yang menyerahkan dirinya pada setiap laki-laki untuk kepentingan seks. Perempuan itu tidak bisa memilih siapa yang akan memakai jasanya secara berturut-turut. Elemen terpenting dalam kepelacuran adalah uang dan mata pencaharian (Anisa, 2019; Koentjoro, 2004).

Dunia prostitusi bukanlah hal baru yang hadir di dalam masyarakat, melainkan masalah lama yang diwariskan oleh nenek moyang kita sebagai sebuah kebudayaan yang sepertinya harus kita lestarikan (Mukramin \& Nawir, 2018). Sekaitan dengan itu, seksualitas merupakan budaya manusia yang tertua. Dengan demikian, usia seksualitas pada hakikatnya setua dengan usia manusia itu sendiri. Di dalam sejarah agama-agama, terutama terkait reproduksi, seksualitas adalah bagian dari proses reproduksi (Syuhudi, 2014). Pekerja Seks Komersial (PSK) adalah salah satu jenis profesi yang mengalami konstruksi sosial buruk dan penuh stigma sampai dikategorikan sebagai sampah masyarakat (Destrianti \& Harnani, 2018). Banyak istilah yang dilekatkan kepada perempuan yang menyerahkan dirinya kepada laki-laki untuk kepentingan seks. Mulai dari Pelacur, Pekerja Seks Komersial (PSK), Sundal, Wanita Tuna Susila (WTS) dan Lonte (Kenedi, 2017; Koentjoro \& Sugihastuti, 1999). Namun tetap saja, dalam istilah Syam, identitas PSK adalah identitas yang tidak transparan atau hidden identity (Syuhudi, 2019). Tindakan melacur dianggap hina karena yang dilakukan menyimpang dari norma agama, moral dan adat, tapi di balik itu semua PSK masih meyakini agama sebagai tuntunan hidup (Hidayatulloh, 2008; Jauhari, 2020). Agama hadir di kalangan PSK berbeda dengan agama yang hadir di kalangan kyai. Agama hadir dalam diri PSK hanya ketika waktu tertentu, yaitu di saat-saat sedang merenung atau dalam kesendirian. Jika Tuhan terasa hadir dalam diri PSK maka seluruh bayangan hidupnya terasa berada dalam kesalahan, sebaliknya jika Tuhan telah pergi maka PSK akan kembali dalam kehidupan semula (Syam, 2011). Pengertian agama dalam konteks ini lebih dekat kepada pernyataan bahwa individu atau kelompok masyarakat yang meyakini bahwa Tuhan itu ada ataupun mengakui adanya dzat yang mempunyai kekuatan supranatural, maka ia sudah dapat dikatakan masyarakat beragama (Khodijah, 2014).

Ketika perintah agama dilaksanakan oleh manusia maka agama mengalami pergeseran makna. Pergeseran tersebut terjadi karena agama bersentuhan dengan kehidupan manusia, seperti kebiasaan, gaya hidup, tingkat kebutuhan ekonomi dan lain-lain. Begitu juga yang terjadi pada PSK yang meyakini agama dan mengetahui bahwa perbuatan melacur yang dilakukan adalah dosa yang dapat mengantar ke neraka, tapi PSK masih melacur, maka dalam konteks ini terjadi proses pergeseran makna yang disebut dengan rasionalisasi. Fenomena keberagamaan manusia dapat dilihat dari berbagai sudut pandang. Fenomena tersebut ditandai dengan normativitas ajaran wahyu, tapi dapat juga dilihat dari historisitas pemahaman dan interpretasi individu atau kelompok terhadap norma-norma ajaran agama yang dipeluknya. Selain itu dapat juga dilihat dari bentukbentuk amalan dan praktik-praktik ajaran agama dalam kehidupan sehari-hari (Abdullah, 1999).

Terdapat beberapa penelitian terkait tema rasionalisasi beragama PSK, di antaranya penelitian (Hidayatulloh, 2008), (Siswanto, 2013), (Marhaeni, 2006) dan (Syam, 2011). Studi Hidayatulloh (2008) menunjukkan bahwa PSK memiliki keyakinan yang kuat terhadap agama yang dianutnya. Mereka tetap berpandangan bahwa agama berisi aturan-aturan yang harus ditaati dan dilaksanakan sebagai pedoman hidup. Dalam praktiknya terdapat PSK yang menjalankan perintah agama dengan taat, hingga melaksanakan ajaran-ajaran yang bersifat Sunnah, selain itu ada PSK yang hanya melaksanakan ibadah wajib dan terdapat pula yang sama sekali tidak melaksanakan ajaran agama.

Studi Ani Marhaeni (2006) tentang perilaku keberagamaan PSK menunjukkan bahwa ada saling keterkaitan antara profesi pekerja seks dengan perilaku keberagamaan PSK, karena profesi sebagai PSK berdampak negatif terhadap perilaku keberagamaan. Bagi PSK yang beragama Islam, tapi tidak melaksanakan shalat lima waktu, meskipun masih membayar zakat. Studi Siswanto (2013) tentang interaksi sosial yang terjadi antara PSK 
dengan masyarakat menunjukkan bahwa meskipun ekonomi yang sangat kuat di lingkungan masyarakat di Sosrowijayan menempatkan masyarakat sebagai pihak yang diuntungkan, sehingga terjalin hubungan PSK berorientasi pada ekonomi, namun doktrin agama tidak memberikan pengaruh pada praktik prostitusi. Studi Syam (2011) menunjukkan bahwa panggung depan PSK yang menampilkan kecitraan; ceria, menarik, keseronokan, polesan lipstik di bibir yang berlebihan dan lain-lain, tetapi dunia panggung belakang menjadi dirinya sendiri. PSK menemukan dunianya, berkomunikasi dengan dirinya dan dengan Tuhannya.

Dari beberapa studi di atas menggambarkan meskipun PSK di panggung depan mempertontonkan dunia yang membelakangi agama, namun di panggung belakang mereka tetap hidup dalam dunia agama. Bahkan sebagian besar PSK justru taat melaksanakan ajaran agama baik yang wajib maupun yang Sunnah. Jika demikian, maka bagaimana memahami perilaku keberagamaan PSK, di mana pada panggung depan perilaku PSK melanggar norma agama, namun di panggung belakang melaksanakan ajaran agama serta meyakini bahwa Tuhan akan mengabulkan doa-doanya. Maka dengan itu, tulisan ini bertujuan melengkapi kekurangan studi di atas yang belum memberi perhatian pada aspek bagaimana PSK merasionalisasikan ajaran agama dalam kehidupan sehari-hari? Dalam upaya memahami rasionalitas yang dibangun oleh PSK, maka beberapa pertanyaan dirumuskan; Pertama apa yang menjadi pertimbangan PSK memilih terjun pada dunia prostitusi? Kedua, bagaimana pandangan PSK terhadap agama dan bagaimana PSK menyatukan dua dunia yang berbeda antara pekerja seks dan agama?.

\section{Kerangka Teori}

Studi ini berargumen bahwa antara tindakan melacur dan tindakan beragama adalah dua hal yang berbeda. Mengulas PSK dan agama, ada masanya dua hal yang berbeda ini dilakukan secara saat bersamaan, namun ada juga masanya PSK harus memilih dari dua hal berbeda itu, memilih melacur atau memilih beragama. Dengan adanya pilihan-pilihan berbeda yang dihadapi pelacur, maka melihat rasionalitas PSK dalam memilih dan bertindak menghadapi dua pilihan berbeda adalah hal yang menarik untuk diulas. Menurut Weber (dalam Shalihin, 2013) rasionalisasi merupakan konsep dasar yang digunakan untuk mengklasifikasi tindakan sosial. Tindakan sosial merupakan suatu tindakan individu yang diarahkan kepada orang lain dan memiliki arti atau makna subyektif baik bagi diri sendiri maupun bagi orang lain (Munir, 2019). Dalam perumusan tentang konsep rasionalisasi, Weber lebih mengarahkan pada proses dengan apa dunia membersihkan magis, mistisisme, dan melenyapkan populasi dewa-dewa, gerombolan setan, dan roh-roh yang semula mengarahkan pelbagai aktivitas mereka dalam sekian banyak sistem kepercayaan (Shalihin, 2013). Yang disebut dengan tindakan rasional adalah tindakan yang sangat bercorak penguasaan dan duniawi, yang mengedepankan utilitas tindakan ketimbang tendensi metafisika. Ciri dari tindakan rasional adalah selalu berorientasi pada value added, yakni sejauhmana suatu tindakan mampu untuk mendatangkan maksimalisasi. Maka pada wilayah ini, keluaran (hasil) dari suatu tindakan adalah ukuran yang harus diperhitungkan dalam melakukan tindakan. Di wilayah lain, rasionalitas tindakan juga sejajar dengan manfaat ataupun keuntungan (utilitas) tindakan, dimana rasionalitas tindakan mengandaikan adanya maximum utility, dimanapun wilayahnya.

Ada dua utilitas yang didapatkan individu, jika melakukan tindakan yang dinilai rasional. Pertama, ia mendapatkan utilitas privat dan kedua ia mendapatkan utilitas sosial. Jeremy Bentham (dalam Shalihin, 2013) membedah persoalan mengapa manusia bertindak dan berbuat demi kebahagiaanya dan manusia memperoleh kebahagiaan hanya melalui pemilihan-pemilihan kepuasan yang rasional? Bentham menawarkan metode "kalkulus kebahagiaan" sebuah pemaknaan terhadap bagaimana manusia mencari kepuasan yang rasional. Dalam prinsipnya yang alamiah, kalkulus kebahagiaan dapat dilacak dari selukbeluk tindakan intensi hasil dari sebuah tindakan. Studi ini mengilustrasikan, jika keadaan rumah tangga, keadaan ekonomi dan agama tidak dapat membuat bahagia, lalu kemudian mengapa beralih memilih menjadi pelacur. Lebih lanjut, jika tindakan melacur adalah tindakan yang bertentang dengan agama, mengapa PSK dapat menyatukan dua hal yang berbeda ini. Maka proses pemilihan ini adalah pilihan rasional ketika rumah tangga, keadaan ekonomi dan bahkan agama tidak mampu menjamin kebahagiaan dari seorang individu. 
Menyambung dengan itu, Bentham merumuskan bahwa dalam jaringan kompleks tindakan rasional, manusia akan selalu berupaya memaksimalkan kepuasan dan meminimalkan kepedihan. Kepuasan dan kepedihan akan mengontrol individu dalam semua hal yang dilakukan, semua hal yang dikatakan, dan semua hal yang dipikirkan (Shalihin, 2013). Begitu juga dengan setiap utiliti dalam jaringan kompleks tindakan rasional selalu melibatkan tindakan sadar, disengaja dan jelas, seperti memilih untuk terjun ke dunia prostitusi. Inilah yang dikatakan sebagai tindakan rasional, ia selalu dihubungkan dengan pertimbangan yang sadar dan pilihan bahwa tindakan tersebut dinyatakan. Secara eksplisit ada 4 (empat) tindakan sosial menurut Weber yang memiliki arti subjektif (Munir, 2019). Pertama tindakan yang berorientasi tujuan (Instrumentally Rasional) yakni tindakan yang ditujukan pada pencapaian tujuan-tujuan yang secara rasional diperhitungkan dan diupayakan sendiri oleh aktor yang bersangkutan. Tindakan ini ditentukan oleh harapan-harapan terhadap perilaku objek dalam lingkungan dan perilaku manusia lain, harapan-harapan ini digunakan sebagai syarat atau sarana untuk mencapai tujuan aktor lewat upaya dan perhitungan yang rasional. Dalam tindakan ini manusia tidak hanya menentukan tujuan yang diinginkan agar tercapai, namun ia harus secara rasional telah mampu memilih dan menentukan alat yang digunakan untuk mencapai tujuan tersebut. Kedua tindakan yang berorientasi nilai (Value Rational) yakni tindakan yang didasari oleh kesadaran keyakinan mengenai nilai-nilai yang penting seperti etika, estetika, agama dan nilai-nilai lainnya yang mempengaruhi tingkah laku manusia dalam kehidupannya. Tindakan ini merupakan suatu rasionalitas masyarakat yang melihat nilai-nilai absolut tertentu sebagai potensi atau tujuan hidup. Nilai-nilai ini dijadikan suatu kesadaran akan perilaku etis, estetis, religius atau bentuk perilaku lain, yang terlepas dari prospek keberhasilannya. Ketiga tindakan afektif (Effectual/especially emotional) tindakan yang ditentukan oleh kondisi kejiwaan dan perasaan (orientasi emosional) aktor yang melakukannya. Tindakan ini merupakan tipe rasional yang sangat bermuara dalam hubungan emosi atau perasaan yang sangat mendalam, sehingga ada hubungan khusus yang tidak dapat diterangkan di luar lingkaran tersebut. Kondisi ini ditentukan oleh kondisi emosi aktor. Dan keempat tindakan tradisional (Traditional) yaitu kebiasaan-kebiasaan yang mendarah daging (mengakar secara turun temurun). Tindakan ini bertujuan untuk memperjuangkan nilai yang berasal dari tradisi kehidupan masyarakat. Tindakan ini ditentukan oleh cara bertindak aktor yang biasa dilakukan dan lazim.

\section{Metode Penelitian}

Tulisan ini merupakan hasil penelitian lapangan yang dilakukan dengan metode penelitian kualitatif. Penelitian dilakukan di Panti Sosial Karya Wanita Andam Dewi Solok. Sumber data dalam penelitian ini ialah para Pekerja Seks Komersial (PSK) yang telah mengalami proses rehab di Panti Sosial Karya Wanita Andam Dewi Solok. Sumber data ditetapkan menggunakan teknik purposive sampling, yang dilakukan sebelum penelitian berjalan. Untuk teknik pengumpulan data, penelitian ini menggunakan wawancara mendalam (indep interview). Dengan menggunakan pedoman wawancara, data-data yang dikumpulkan terkait: Pertama pertimbangan PSK memilih untuk terjun pada dunia prostitusi. Kedua, pandangan pekerja seks komersial (PSK) terhadap agama yang mereka yakini dan Ketiga bagaimana PSK menyatukan dua dunia yang berbeda antara pekerja seks dan agama? Analisis dalam penelitian ini dilakukan beberapa tahap: pertama manajemen data, kedua; memoing data, ketiga display data dan keempat penarikan kesimpulan. Manajemen data dilakukan dengan cara pentranskripan hasil wawancara bersama PSK, dari audio ke dalam bentuk narasi. Memoing data dilakukan dengan cara memberikan tanda-tanda atau catatan-catatan terhadap hasil wawancara yang telah ditranskrip. Setelah data ditranskrip dan diberikan tanda, data wawancara dari PSK dipilih dan dikelompokkan sesuai dengan pertanyaan yang diangkat di dalam penelitian. Display data dilakukan dengan menyajikan data ke dalam bentuk narasi deskriptif dan kemudian diinterpretasi sesuai dengan pendekatan yang digunakan dalam melihat rasionalisasi agama pekerja seks komersial (PSK) di Panti Sosial Karya Wanita Andam Dewi Solok.

\section{Hasil dan Diskusi}

\subsection{Cerita Panjang Memilih Melacur}

Studi ini menemukan latar belakang dari beberapa PSKyang telah direhabilitasi di rumah rehab Andam Dewi Kabupaten Solok. Pertama, mereka adalah orang-orang yang berasal dari keluarga broken home dan kurang mendapatkan perhatian dari kedua orang tua. 
Seperti yang berinisial KA, perempuan yang dulunya bekerja sebagai PSKini mengalami keretakan dalam keluarganya intinya. Antara ayah dan ibunya, memilih jalan untuk berpisah yang saat ini masing-masing keduanya sudah memiliki keluarga baru. Meskipun komunikasi antara kedua orang tuanya dengan KA masih berjalan dengan baik, tetapi perhatian yang didapatkan dan kasih sayang yang dibutuhkan, tidaklah sama sewaktu keluarga KA masih bersatu. Alhasil peristiwa itu berimplikasi panjang kepada diri KA. Bagi KA profesinya "melacur" tidaklah menyenangkan tetapi ketika mendapatkan uang dari hasil pekerjaan sendiri rasanya bahagia karena merasa telah mampu memenuhi kebutuhan hidup sendiri. Begitu juga dengan perempuan berinisial LA. Dia seorang perempuan pekerja seks komersial yang dulunya pernah menjadi istri dari seorang laki-laki. LA seorang ibu yang memiliki 5 (lima) orang anak, 2 (dua) perempuan dan 3 (tiga) laki-laki. Kesuksesan suami LA dalam berkarir menjadi pemicu dalam keretakan rumah tangganya. Sehingga rumah tangga yang telah dijalani LA selama 16 tahun, berakhir dengan perceraian.

Tidak disangka rumah tangga yang kami bina selama 16 tahun harus berakhir dengan perceraian. Ini terjadi karena suami saya ketika dia sudah sukses sudah banyak saja perempuan lain yang mau dengannya. Dan sekarang dia sudah menikah lagi dengan perempuan Solok Selatan. Anak saya paling tua umur 18 tahun sudah kelas 2 SMA berhenti sekolah karena kami bercerai. Anak saya 5 orang, 2 perempuan dan 3 laki-laki (Wawancara, LA 2 Desember 2019).

Kedua, mereka adalah orang-orang yang secara finansial kurang berkecukupan dan tingkat pendidikannya hanya sampai Sekolah Menengah Pertama (SMP) dan Sekolah Menengah Atas (SMA). Seperti perempuan yang berinisial SA. Perempuan PSKyang berusia 17 tahun, terpaksa berhenti di bangku kelas 2 (dua) SMP disebabkan masalah ekonomi. Permasalahan finansial juga dialami oleh NA. Perempuan ini merupakan pekerja seks komersial yang sudah berkeluarga. Kegiatan melacur dijadikan sebagai profesi untuk memenuhi kebutuhan anak-anaknya. Bagi NA, melacur hanya untuk memenuhi kebutuhan finansial untuk menghidupi anak-anaknya. Melacur bagi NA adalah suatu jalan alternatif yang dapat memenuhi kebutuhan keluarganya.

Sebenarnya saya merasa terbebani bekerja di sini tetapi karena perekonomian ya terpaksalah karena tidak ada pilihan lain. Sudah saya coba bekerja di tempat lain tetapi tidak mencukupi untuk keluarga apalagi sekarang semuanya serba mahal. Bekerja hanya tergantung kekuatan fisik kita aja, misalnya kita hanya sanggup dua orang saja ya udah dua orang itu saja, saya tidak terlalu difokuskan jika sudah dapat duit ya udah dan saya tidak milih-milih selagi ada ya gak apa-apa (Wawancara, NA 2 Desember 2019).

Dua latar belakang yang disebutkan di atas adalah gerbang untuk mengantarkan ke tindakan perempuan ke dalam dunia pelacuran. Walaupun studi lain mengatakan bahwa faktor ekonomi (Munawaroh, 2010) dan kebudayaan juga menjadi faktor terjadinya transaksi prostitusi seperti studi Worcester (2002) di Desa Dukuh Seti, Parangkusumo, dan Gunung Kemukus. Studi ini menemukan bahwa latar belakang yang dialami oleh perempuan-perempuan telah menjadi batu loncatan untuk berkenalan dengan dunia pelacuran. Jika diperdalam lagi, ternyata mengenal dunia pelacuran berawal dari akses sumber daya yang sudah awal terlebih dahulu mengenali dunia transaksi seks tersebut. Formulasi akses ini dapat membuka hubungan paralel antara perempuan yang belum melacur dengan perempuan yang sudah mengenali dunia pelacur. Pelacur berinisial SA misalnya, mengenali dunia prostitusi disebabkan karna adanya relasi-relasi, yang semakin jauh relasi tersebut semakin berkembang. SA menyatakan dalam wawancara "...... saya masuk ke dunia prostitusi karena dibawa-bawa teman, mereka membawa saya dengan cara dikenalkan dengan satu teman dan teman tersebut mengenalkan ke teman-teman yang lainnya" (Wawancara, SA 13 Januari 2020). Begitu juga dengan LA. Perempuan ini juga dikenalkan dengan dunia prostitusi disebabkan oleh relasi-relasi yang dimilikinya. LA diajak oleh temannya untuk masuk dunia prostitusi. Perempuan ini mau mengikuti ajakan temannya karena di dunia prostitusi mereka digaji dengan uang yang jumlah besar. Sedangkan bekerja di tempat lain seperti di toko tidak mampu memenuhi kebutuhan sehari-harinya. Kebutuhan terhadap meterialistik yang besar menjadi poin penting, mengapa perempuan melakukan tindakan melacur. Sehingga dengan begitu, motif yang demikian menjadikan semacam pola tindakan yang terus dilakukan secara berulang-ulang. KA misalnya, tidak kecil kebutuhan yang diperlukannya untuk memenuhi kebutuhan sehari-hari. Ini bukan soal sikap yang hedonis, melainkan karna kebutuhan naluri sebagai perempuan. 
Pada awalnya saya bekerja di toko gajinya hanya 30 ribu sehari, uang segitu mana cukup untuk makan tiga kali sehari, beli baju dan kebutuhan perempuan lainnya. Pada mulanya saya diajak teman bekerja di café hanya untuk bernyanyi, lama-lama saya di sini akhirnya saya melayani seks laki-laki. Gajinya lumayan besar kadang semalam dapat uang 400 sampai 500 ribu, belum lagi jika kita melayani seks laki-laki, apalagi kita masih muda ini dibayar mahal kadang sampai jutaan (Wawancara, KA 13 Januari 2020).

Relasi tidak hanya memanfaatkan, tetapi juga dapat dimanfaatkan. Seperti SA yang berbeda dengan pekerja seks komersial lainnya. SA menyelami dunia pelacuran hanya untuk hiburan. Dia menghibur dirinya agar ia dapat melupakan masalah yang menjadi beban baginya dan dia menganggap uang yang ia dapatkan dari pekerjaan melacur sebagai bonus dari hiburannya karena dia masih mendapatkan uang dari orang tuanya.

Yang saya cari hanyalah hiburan untuk diri sendiri. Saya senang mengikuti teman-teman saya ini, semua masalah terasa hilang yang dirasakan hanyalah kesenangan. Saya juga melayani laki-laki yang saya temukan di café tempat nongkrong sama teman-teman dan ini menghasilkan uang dan saya anggap bonus dari hobi (Wawancara, SA 2 Desember 2019).

Data di atas menunjukkan bahwa, pilihan untuk terjun ke dunia prostitusi merupakan tindakan rasional yang dilakukan oleh perempuan pelacur. Tindakan melacur yang dilakukan dalam studi ini ditujukan untuk mencapai tujuan-tujuan tertentu. Menariknya, kepentingan itu tidak hanya ditujukan untuk kepentingan pribadi, namun juga ditujukan untuk memenuhi kebutuhan individu lain di dalamnya. Studi ini menemukan, besarnya bayaran yang diperoleh perempuan PSK dari hasil transaksi seks yang dilakukan, tidak hanya diperuntukkan untuk diri sendiri (pelacur) namun juga digunakan untuk kepentingan keluarga dan anak-anak dari pelacur. Jika meminjam konsep Weber dalam mengidentifikasi tindakan, maka dapat dikatakan bahwa tindakan melacur yang dilakukan adalah tindakan yang berorientasi tujuan (instrumentally rasional) (Turner, 2012). Tindakan melacur yang dilakukan PSK sebagai aktor yang bersangkutan, secara rasional diupayakan untuk mendapatkan utility, baik untuk menampakkan "dirinya" sebagai perempuan ataupun untuk menampakkan dirinya sebagai orang yang bertanggungjawab di dalam keluarganya. Tindakan seperti ini ditentukan oleh harapan-harapan terhadap perilaku objek dalam lingkungan dan perilaku manusia lainnya. Harapan-harapan ini digunakan sebagai syarat atau sarana untuk mencapai tujuan melacur melalui upaya dan perhitungan yang rasional. Untuk mencapai tujuan, studi ini menemukan upaya yang dilakukan PSK dengan membangun relasi-relasi yang menguntungkan. Sehingga PSK sebagai aktor, tidak lagi memperhitungkan apakah tindakan melacur itu bertentangan dengan norma dan nilai yang berlaku di dalam masyarakat. Tetapi yang jelas tujuan untuk memenuhi berbagai macam kebutuhan, dapat dipenuhi dengan tindakan melacur dan itu adalah bagian tindakan rasional yang berorientasi tujuan bagi perempuan PSK (Ritzer, 2014).

\subsection{Tindakan Melacur dan Beriman}

Studi Nur Syam (2011) tentang Agama Pelacur menjelaskan bahwa bagi PSK agama adalah urusan privat. Agama dapat muncul dan hadir dalam bilik-bilik kecil ketika mereka berada dalam kesunyian. Studi Nursam memberikan bukti bahwa PSK yang selama ini dipandang sebagai individu yang jauh dari yang namanya "agama", ternyata tidaklah demikian. Dengan teori dramaturgi menunjukkan bahwa mereka (pelacur) adalah orang-orang yang bijaksana dalam memainkan peran (individu beragama). Adakalanya mereka berperan sebagai perempuan pelepas hasrat birahi, tetapi ada juga kalanya mereka berperan sebagai hamba dari Sang Pencipta.

Bagi PSK, agama (Tuhan) adalah sesuatu Maha-Suci yang memiliki dua sisi. Dia (Tuhan) dapat mendatangkan rezeki dan juga dapat memberikan dosa. Studi ini menemukan bahwa perempuan pekerja seks komersial sadar atas tindakan melacur yang dilakukan adalah sesuatu yang dilarang di dalam agama. Maka perempuan PSK yakin bahwa tindakan melacur itu akan mendapatkan dosa. Di sisi lain, studi ini juga menemukan bahwa bayaran yang didapat dari hasil melacur yang dilakukan secara berulang-ulang diyakini sebagai rezeki yang diberikan oleh agama (Tuhan). Pelacur tidak menyalahkan agama atas tindakan melacur yang dilakukan, tetapi ada sesuatu mengapa tindakan melacur itu tetap dilakukan. Inisial NA sebagai perempuan pekerja seks komersial mengetahui bahwa tindakan melacur adalah tindakan yang berdosa. Bagi NA keadaanlah yang membuatnya untuk memilih dunia prostitusi. NA masih menganggap uang dari hasil pekerjaannya melacur adalah rezeki dari Tuhan yang patut disyukuri. 
Setiap pekerjaan pasti ada dosanya, tapi karena keadaan tadilah. Jika dipikirkan dosa ya saya takut, ya itu tadilah karena keadaan. Duit yang saya dapatkan dari pekerjaan tersebut masih saya anggap rezeki dari yang di atas, saya juga bersyukur kok kepada Allah atas rezeki yang dia kasih (Wawancara, NA 2 Desember 2019).

Besarnya angka untuk memenuhi kebutuhan hidup sehari-hari, perempuan PSK merelakan untuk mendapatkan dosa. KA perempuan Muslim yang menjadi pekerja seks komersial, juga menyadari dosa dari tindakan melacurnya. Berdosa tentu berdosa, namun perekonomian rendah sehingga KA tidak dapat keluar dari kekangan kemiskinan itu. Ditambah lagi dengan usianya tergolong muda, bagi KA adalah masa yang hal semacam melacur tidak masalah untuk dilakukan. Kembali ke arah yang lebih baik bagi KA adalah sebuah pengharapan yang dinantikan. Waktu dan kapan tidak bisa ditentukan untuk meninggalkan dunia malam yang bergelimang dosa. Terkadang saat teringat orang tuanya KA merasa bersalah dan ingin bertobat. Tetapi setelah ingatan itu hilang maka rasa ingin bertobat tadi pun ikut hilang. KA menyadari dunia malam tersebut merupakan jalan yang salah tetapi kondisi ekonomi membuat KA tetap berkecimpung di dunia malam.

Saya seorang Muslim, sebenarnya masalah dosa itu ada terpikir, tapi karna faktor keadaan ya gimana lagi, selagi muda apa salahnya dicoba. Jika saya sudah punya suami barulah saya berubah ke arah yang lebih baik pakai jilbab, rutin salat dan menjauhi narkoba. Terkadang di saat sedang melayani lelaki saya teringat mama, baru ingat dosa dan ingin bertobat tetapi itu hanya sebentar dan lupa lagi. Terkadang ada saya terpikir ini jalan yang salah tapi kembali lagi ke keadaan, keadaanlah yang memaksa saya untuk seperti ini (Wawancara, KA 2 Desember 2019).

Selain itu, bagi perempuan PSK agama tidak hanya memiliki dua sisi yang dapat mendatangkan rezeki dan dosa, tetapi agama juga dijadikan sebagai kanal penyeimbang atas tindakan melacur yang dilakukan. Antara dunia fisik dan dunia metafisik bagi PSK adalah dua hal yang berbeda. Dunia fisik adalah dunia tempat memuaskan nafsu birahi dengan tindakan transaksi seks yang dilakukan secara berulang. Sementara dunia metafisik (agama) adalah dunia tempat penyesalan dan pengaduan untuk memuaskan nafsu spiritual yang dilakukan dengan tindakan-tindakan keagamaan. Terlihat seperti apa yang dilakukan oleh LA, yang secara konsisten melakukan dua hal yang berbeda. LA melakukan tindakan melacur, di lain sisi LA juga melakukan berbagai macam praktikpraktik keagamaan.

Saya sangat yakin apapun perbuatan pasti ada dosanya. Selesai bekerja, saya teringat dosa dan
saya selalu ingat bagaimana nanti kalau saya mati dosa saya banyak. Makanya saya salat dan
puasa untuk menghapus dosa saya yang banyak ini. Saya tidak pernah memikirkan diterima
atau tidaknya salat saya, karena itu urusan Allah yang penting saya kerjakan. Dan malah saya
juga salat tahajud kadang-kadang. Di setiap salat, saya selalu minta ampun atas segala dosa
dan kesalahan saya. Apakah tidak ada lagi ampunan Allah untuk saya? tetapi besoknya setelah
selesai salat saya kerjakan lagi perbuatan tersebut ya bagaimana lagi saya butuh pekerjaan itu.
Seburuk apapun pekerjaan saya, saya akan selalu salat walaupun sesekali. Pulang dari kafe
kadang-kadang hati saya tidak nyaman saya ambil wudhu saya bawa salat dan saya baca
Yasin sampai saya dibilang gila sama teman karena sesudah berbuat maksiat saya bertobat
(Wawancara, LA 13 Januari 2020).

Bagi pelacur, agama tidak dipandang sebagai doktrin yang mengekang. Melainkan dipandang sebagai doktrin yang memberikan kebebasan terlebih lagi mampu memberikan pengharapan, agar dapat menebus dosa dari tindakan melacur yang dilakukan. Dualitas ini tidak hanya dilakukan dengan tindakan-tindakan spiritual seperti; shalat, puasa dan segala macamnya, namun juga dapat dilihat dari tindakan-tindakan filantropi. Studi ini menemukan, bahwa para perempuan PSK juga mengkonversikan bayaran hasil dari tindakan melacurnya ke dalam tindakan kedermawanan. Seperti yang dilakukan KA, mengkonversikan uang hasil dari melacur untuk bersedekah kepada orang yang membutuhkan. Begitu pula dengan NA, perempuan PSK yang mampu melayani laki-laki 2 (dua) orang dalam satu malamnya, tidak hanya sedekah, NA pun membayar zakat pribadi dan bahkan zakat 2 (dua) orang anaknya dengan menggunakan hasil dari tindakan melacur yang dilakukannya. LA juga demikian, perempuan PSK yang menginspirasikan kata-kata Buya Hamka "jangan takut untuk jatuh, karena yang tidak memanjatlah yang tidak pernah jatuh" mampu memberikan 30.000 sampai 50.000 rupiah dari hasil yang didapat untuk diberikan kepada orang yang membutuhkan. Tindakan derma yang dilakukan oleh para perempuan pelacur, tidak lain dan tidak bukan hanya dianggap 
sebagai tebusan atas tindakan melacur yang dilakukan. Mereka menyadari bahwa dirinya adalah "perempuan bergelimang dosa", dengan kedermawananlah hal itu ditutupi.

Paparan data di atas memperlihatkan bahwa walaupun perempuan di dalam studi ini melakukan tindakan yang dianggap bertentangan dengan norma yang berlaku di masyarakat, namun aspek agama tetap ada di dalam diri pelacur. Agama malah menjadi sebagai basis dalam penguatan dan legitimasi tindakan sosial yang akan dilakukan oleh para perempuan pelacur. Dengan demikian, dapat dikatakan bahwa sebenarnya PSK telah melakukan eksplorasi antara pekerjaan yang dilarang dengan agama dengan pekerjaan yang dianjurkan oleh agama. Eksplorasi semacam itu adalah hasil dari rasionalitas pelacur. Rasionalitas semacam ini merupakan rasionalitas beragama yang tidak biasa ditemui di kalangan-kalangan pemeluk agama biasa. Bagi perempuan PSK tujuan absolut (material) dijadikan rasional dengan merujuk sarana ketidakberdayaan, sehingga dalam praksisnya simbol-simbol agama dapat dimodifikasi sesuai dengan keadaannya. Bentuk modifikasi yang dilakukan seperti berzakat dan bersedekah dengan menggunakan hasil dari transaksi seks yang dilakukan mereka. Modifikasi simbol-simbol agama yang demikian juga ditemukan dalam Studi Nur Syam (2011), yang meneliti "Agama Pelacur" di Surabaya. Yang menarik dari penelitian Syam adalah ia mengamati sisi-sisi religiositas dari pelacur, yang belum pernah diulas oleh peneliti lain. Artinya, meskipun mereka sadar, bahwa pekerjaan yang dilakoni itu perbuatan dosa. Namun, di antara PSK itu tetap ada yang menjalankan shalat wajib, bersedekah ke rumah ibadah atau ke pengemis, serta berpuasa di bulan Ramadan. Di dalam kegelapan, pasti masih ada sisi terang.

Bagi perempuan pelacur, antara melacur dan beragama, keduanya memiliki relasi yang sama-sama menguntungkan. Melacur dapat memberdayakan keluarga dan meningkatkan perekonomian, sementara agama dapat mengurangi dan menghilangkan dosa dari perbuatan melacur. Agama tidak saja dimaknai sebagai doktrin yang hanya mengatur pada aspek ritual saja seperti shalat, puasa dan segala macamnya, namun lebih dari itu agama dimaknai sebagai obat penawar untuk setiap tindakan seks yang dilakukan pada setiap malamnya. Sehingga, yang awalnya mereka yakini tindakan melacur itu memiliki dosa, dengan adanya keyakinan agama seperti itu, dosa yang diperoleh dapat ditebus melalui simbol-simbol agama yang telah dimodifikasi. Eksplorasi seperti ini yang menghasilkan perempuan-perempuan PSK akan selalu tetap melakukan tindakan-tindakan transaksi seks bersama pelanggannya. Jika mengikuti logika Weber (Turner, 2012), maka yang dilakukan oleh para PSK merupakan tindakan yang memiliki orientasi nilai (value rational). Mereka memadukan antara tindakan melacur dan memodifikasi praktik simbol-simbol agama dengan penuh kesadaran. Tindakan ini merupakan suatu rasionalitas dari PSK yang melihat nilai-nilai absolut, sebagai potensi atau tujuan hidup bagi mereka.

\section{Kesimpulan}

Studi ini menunjukkan ternyata ada corak dan pola yang berbeda di kalangan perempuan PSK dalam melihat apa yang disebut dengan "agama". Mereka memiliki rasionalitas tersendiri dalam memisahkan dan mempertemukan dua hal yang berbeda, antara tindakan melacur dan tindakan agama. Dua wilayah tersebut, apakah melacur dan tindakan agama dipisah atau sebaliknya, bagi PSK kedua-duanya wilayah itu memiliki value dan orientasi yang jelas, baik materi ataupun kesenangan belaka. Walaupun demikian, studi ini hanya terbatas pada wilayah pendeskripsian rasionalitas yang sudah dimiliki oleh perempuan pelacur, belum menyentuh bagaimana proses pembentukan rasionalitas PSK dalam memahami agama.

\section{Ucapan Terima Kasih}

Ucapan terima kasih disampaikan kepada semua pihak yang telah membantu proses penelitian, penulisan dan publikasi artikel ini.

\section{Konflik Kepentingan}

Penulis menyatakan bahwa tidak ada konflik kepentingan antar penulis dan subjek penelitian dalam penulisan artikel ilmiah ini.

\section{Daftar Pustaka}

Abdullah, A. (1999). Agama Normativitas atau Historitas? (Cetakan II). Pustaka Pelajar.

Anisa, L. N. (2019). Pelacuran dan Strategi Dakwah. Al-Mabsut: Jurnal Studi Islam Dan Sosial, 13(1), 105-119. 
Destrianti, F., \& Harnani, Y. (2018). Studi Kualitatif Pekerja Seks Komersial (PSK) di Daerah Jondul Kota Pekanbaru Tahun 2016. Jurnal Endurance, 3(2), 302-312. https://doi.org/10.22216/jen.v3i2.1021

Hidayah, S. N. (2016). Perilaku Sosial Pekerja Seks Komersial. Jurnal Ijtimaiya, 2(1), $111-$ 134.

Hidayatulloh, S. (2008). Pemahaman Agama Islam Pada Pekerja Seks Komersial (Studi Kasus Psk Lokalisasi Komplek Kedung Banteng Desa Kedung Banteng Kecamatan Sukorejo Kabupaten Ponorogo). niversitas Islam Negeri Sunan Kalijaga Yogyakarta.

Jauhari, G. N. A. (2020). Eksistensi Menjadi Pelacur Dalam Novel Tuhan, Izinkan Aku Menjadi Pelacur! Karya Muhidin M. Dahlan. Diglosia: Jurnal Pendidikan, Kebahasaan, Dan Kesusastraan Indonesia, 4(2), 159-174.

Kenedi, J. (2017). Prostitusi dalam Perspektif Hak Asasi Manusia dan Islam (Studi Kasus Praktek Prostitusi di Kota Bengkulu). Mizani: Wacana Huku, Ekonomi Dan Keagamaan, 4(1), 1-8. https://doi.org/10.29300/mzn.v4i1.1003

Khodijah, S. (2014). Rasionalitas Nilai-nilai Agama dalam Kehidupan Perempuan Pekerja Seks. Jurnal Ilmiah Sosiologi Agama, 6(1), 69-84.

Koentjoro. (2004). On the Spot: Tutur dari Sarang Pelacur (D. Nurdin (ed.)). Tinta.

Koentjoro, \& Sugihastuti. (1999). Pelacur, Wanita Tuna Susila, Pekerja Seks, Dan "Apa Lagi": Stigmatisasi Istilah. Humaniora, 11(2), 30-33.

Marhaeni, A. (2006). Perilaku Keberagamaan di Kalangan Pekerja Seks Komersial di Desa Legon Wetan Kecamatan Legon Kulon Kabupaten Subag. Universitas Sunan Kalijaga.

Mukramin, S., \& Nawir, M. (2018). Kehidupan Prostitusi dan Agama (Studi Fenomenologis Pekerja Seks Komersial di Tanjung Bira Kab. Bulukumba). Postkrit: Journal Sociology of Education, 6(1), 21-32. https://doi.org/10.26618/equilibrium.v6i1.1794

Munawaroh, S. (2010). Pekerja Seks Komersial (PSK) di Wilayah Prambanan, Kabupaten Klaten, Jawa Tengah. Dimensia, 4(2), 69-82.

Munir, K. R. \& M. (2019). Jihad Harta dan Kesejahteraan Ekonomi pada Keluarga Jamaah Tabligh: Perspektif Teori Tindakan Sosial Max Weber. Justicia Islamica: Jurnal Kajian Hukum Dan Sosial, 16(1), 193-218. https://doi.org/10.21154/justicia.v16i1.1640

Ritzer, G. (2014). Teori Sosiologi; Dari Sosiologi Klasik Sampai Perkembangan Terakhir Posmodern (12th ed.). Pustaka Pelajar.

Shalihin, N. (2013). Rasionalisasi Agama Dalam Arena Politik: Dari Politik Identitas ke Politik Rasional (Lihin (ed.); 1st ed.). Imam Bonjol Press.

Siswanto, B. B. (2013). Prostitusi Di Sosrowijayan Yogyakarta (Studi Interaksi Pekerja Seks Komersial Pasar Kembang Dengan Masyarakat Sosrowijayan. Universitas Islam Negeri Sunan Kalijaga Yogyakarta.

Syam, N. (2011). Agama Pelacur: Dramaturgi Transendental (I). LKiS.

Syuhudi, M. I. (2014). Gaya Hidup Pelacur Di Makassar. Al-Qalam, 2O(1), 89-96. https://doi.org/10.31969/alq.v20i1.177

Syuhudi, M. I. (2019). Tubuhku Milikmu: Imajinasi Seksualitas pada Tubuh Artis. Mimikri, $5(1), 68-76$.

Turner, B. S. (2012). Teori Sosial dari Klasik sampai Postmodern (Terjemahan). Pustaka Pelajar.

Worcester, A. (2002). Pelacuran dalam Konteks Budaya. Universitas Muhammadiya Malang Bekerjasama dengan ACICIS Study Indonesia Program. 